\title{
Suddha Dharma Mandalam Bhagavad Geeta: The Aryan Philosophy Current Today
}

\author{
Carlos Munoz ${ }^{1,2}$, Alicia Panzitta ${ }^{3}$, Jose Rugue ${ }^{4}$, Domingos Oliveira5, Manuel Paz \\ ${ }^{1}$ Suddha Dharma Mandalam, Santiago, Chile \\ ${ }^{2}$ University of Chile, Santiago, Chile \\ ${ }^{3}$ Ashrama Suddha Dharma, Buenos Aires, Argentina \\ ${ }^{4}$ Suddha Sabha Yoga Ashram, Araguari, Brazil \\ ${ }^{5}$ Ashram Suddha Dharma, Montreal, Canada \\ ${ }^{6}$ Sanatana Dharma School, Cestona, Spain \\ Email: *gdcarlosmunoz@gmail.com
}

How to cite this paper: Munoz, C., Panzitta, A., Rugue, J., Oliveira, D., \& Paz, M. (2020). Suddha Dharma Mandalam Bhagavad Geeta: The Aryan Philosophy Current Today. Open Journal of Philosophy, 10, 220-233

https://doi.org/10.4236/ojpp.2020.102015

Received: April 10, 2020

Accepted: May 15, 2020

Published: May 18, 2020

Copyright $\odot 2020$ by author(s) and Scientific Research Publishing Inc. This work is licensed under the Creative Commons Attribution International License (CC BY 4.0).

http://creativecommons.org/licenses/by/4.0/

cc) (i) Open Access

\begin{abstract}
Suddha Dharma Mandalam (SDM) is name of an ancient Hierarchy which watches over the evolutionary progress of the Humanity. In the whole Universe the Bhagavad Gita-the Yogic art of Brahman-occupies the most exalted position. The aim of this study is to explain the composition and the mystic-philosophical principles that sustain SDM Bhagavad Gita of 745 slokas and 26 chapters. Suddha Gita contains 745 verses in 26 chapters conformed by the dual extreme "The Pranava" (first and last chapters) and the central body "The Gayatri" of 24 chapters (4 feet). The first (Proem) and last one (Epilogue) represent Vyasthi- and Samasthi-para aspects of The Pranava; these aspects correspond to the Brahman conception of One and Many, respectively. While 4 feet or headings (Gñana-knowledge, Bhakti-desire, Karma-action and Yoga-synthesis) correspond to 4 aspects of eternal Dharma and the 4 keys for life learning (quadruple life-path), the 24 chapters represent the 24 material tatwas. By the other hand, the greatest symbols known are The Pranava or the syllable Om and The Gayatri consisting of 24 syllables. The syllable of Pranava contains 2 expressions: 1) the analytical three-letters AUM which normally appear at the beginning of important mantras, where the first letter represents Atma or the Self-aspect of Brahman; U the Prakriti or the Not-self aspect; M the Shakti or the Force-aspect; 2) the synthetical two-letters OM which normally appear at the end of important mantras, where $\mathrm{O}$ (pronounced at center of the palate) integrates the 2 extreme vowels and M similar like before. The AUM at the beginning signifies that Brahman is the source from which the factors manifest themselves, and $\mathrm{Om}$ at the end signifies that these factors merge and become synthesized in that very Brahman. No reference has been made to the reason for the intro-
\end{abstract}


duction by the author of the first and the twenty-sixth chapters and his linking them with the body of the twenty-four chapters compacted together under the four groups. The whole of the current recension is divided into 18 chapters and empirically divided into three shatkas-Kriya, Bhakti and Gñana shatkas, which are based on "tripada gayatri", although Gayatri to be complete has to be "chatuspada-shadangula" representing the well-known 24 principles, six in each pada. The absence, thus, of a fourth pada as such is a serious unfortunately omission. Today Suddha Gita is valid and it is being read by many people around world, since SDM Order as an outer organization has several schools distributed in American and European countries.

\section{Keywords}

Suddha Dharma Mandalam, Bhagavad Geeta, Pranava, Gayatri

\section{Introduction}

Suddha Dharma Mandalam (SDM) is name of an ancient Hierarchy which watches over the evolutionary progress of the Humanity. In the whole Universe the Bhagavad Gita-the Yogic art of Brahman-occupies the most exalted position. This is not merely a book or work on the teachings of the Supreme Lord Shri Krishna, but it is the Law based on love like the law of gravitation always working and functioning in the world. The teaching of Yoga, the Gracious Lord delivered to Arjuna on the battle-field of Kurukshetra for the benefit of humanity in general. As expected, different commentators differently commented upon the mystic meaning of Gita. The Gita with its rich and many-sided expression of thoughts, its synthetical grasp of Karma, Bhakti and Gñanam is unique in the Universe. SDM Bhagavad Gita included all these three aspects in the synthesis called Yoga allowing the culture of the whole man. By the expression the whole man it means those persons whose lower nature has been subdued and is under perfect control, while their higher nature has been fully unfolded. In addition, the great and main aim is to inculcate the supreme lesson that the Spirit in a man is no other than a fragment of the universal Divine Spirit. The Suddha Gita contains 745 verses in 26 chapters or adhyayas under 4 main headings known as Gñana-, Bhakti-, Kriya- and Yoga-shatkas, which constitute the 4 feet of Gayatri or "Chatuspada gayatri". The distribution of this text has received support but also criticism. For instance, the German Philosopher Otto Schrader's claims, based on a traditional "textual version" of 700 slokas and 18 chapters, have been very influential giving room to ideological differences and controversies by various schools (Schrader, 1938). A recent debate over "recensions" of the Bhagavadgita on the search of an "original Gita" has been discussed by Adluri, who in relation to Suddha Gita says: "the Hamsayogin's Gita is not read today" (Bagchee \& Adluri, 2016). By the other hand, some authors have also mentioned that SDM organization does not exist anymore (Reigle, 2007). 
In the following 4 sections we explain the origin and composition and philosophy of Suddha Bhagavad Gita, answer to the criticisms and the current position of SDM organization in the world.

\section{Origin of Suddha Gita}

According to Suddha literature, Suddha (pure) Dharma (eternal laws) Mandalam (organization) (SDM) is the name of an ancient Hierarchy that watches over the evolutionary progress of the Humanity which was reconstituted by the Head of the Hierarchy, Bhagavad Sri Narayana, twelve thousand years ago, that is about a thousand years after the great Mahabharata War. This constitution consists of 32 Siddhas under the august presidency of the Bhagavan and Sri Yoga Devi, who is deemed as the immediate Executrix of His Divine Will. Its subtle Headquarter is located in the regions of the Himalayas known as Uttara-Badari. Although this Hierarchy is very ancient, it was revealed to the world in 1915 (Janardana, 1951a), preserved as a papyrus-Text was in one of the rock libraries in the Hymalayas, inaccessible to any human agency, along with various other palm-leaf manuscripts referring to the real culture heritage of mystic antiquity for which alone this land of Aryavarta is great, the release of this correct Text of Sri Bhagavad Gita was a sheer act of grace by the Yogic-custodians in charge. They did this through the agencies of the late Swami Subramanyananda (Dr. Sir. Subramanier) (1st External Authority) and Pandit K. T. Sreenivasacharyar (2nd External Authority), then there were no fitter persons either in scholarliness or devotion or selfless-service, and faith in the divine Hierarchic governance of the world, to act as channels, even as the Great Ones deemed them so. While $\mathrm{Dr}$ Subramania was a prestigious Judge of the High Court of Madras and Vice-Chancellor of the University of Madras, the revered Pandit was an expert sankritist. It is well-known that sacred Order SDM was announced to the world by Dr. Subramania in article, "An Esoteric Organization in India", published in 1915 in The Theosophist (Subramania Iyer, 1915), while Suddha Bhagavad Gita was edited by Pandit Sreenivasachariar in 1917 (Sreenivasachariar, 1917).

In assessing the value of SDM Sri Bhagavad Gita, one has to grant this divine Hierarchic source from which it came, as a possibility though not as a matter of faith. This text is impossible to be produced by the cleverest of the human beings, even though they might have attained yogic states. Sage Krishna Dwipayana Vyasa alone is the author of this version, having incorporated it in the Mahabharata. And Sage Vaisampayana swears that this Sri Bhagavad Gita has 745 slokas and here the Text is produced; and because the advent of this Text is not in accordance with what is termed as "discoveries" of the so-called scientific researches, but has a mystical background, the secular scholarship overpowering spiritual reasoning should not become chary in assessing its worth and acceptance. Sri Bhagavad Gita of SDM is a veritable treasure, a nectar of knowledge and wisdom, never known before and to miss it is a veritable misfortune (Janardana, 1951b). 
The age of the Gita, according to the Suddhas, may be said to be about a hundred and thirty centuries ago, as a result of the computation of the Kali epoch. The discourse has also been referred to as administered on the seventh day of the bright fortnight of Kartika month, that the occasion was marked by the asterism "Sravana" (Vasudeva Row, 1938).

\section{Colloquium Krishna-Arjuna in Suddha Gita}

In which plane was this sacred dialogue carried out? In the historical epic poem, "The Lord" seized the occasion to give his miraculous teaching, when, at very commencement of the battle, Arjuna, overcome by the greatest enemy of human beings known as "Swartha-dosha" lost his nerves in spite of the benediction showered on him by the divine mother "Sri Yoga Devi" in the form of Durga, and surrendered himself to the Lord to lift him up from the peril of faintness to which he became subjected to. That this teaching by the Lord can never be in terms of chapters and verses since there was a time of "pravrithe sastra sampade", starting the shooting of arrows; it was confined to only one sloka by the Lord, namely, "sarvadharman parithyajya mamékam saranam wraja, aham tva sarva pape" "byo mokshaish yami masusaha", which is declared as the Gayatri; that the entire colloquy between Arjuna from the time of his surrender and the Lord delivering his Gayatri-message was in the nature of an exclusively mental exchange or probably at subtler consciousness plane. How can we understand this?

The teaching-message Master-Disciple varies according to the communicational exchange levels. Figure 1 shows the material planes or wrappers (koshas)

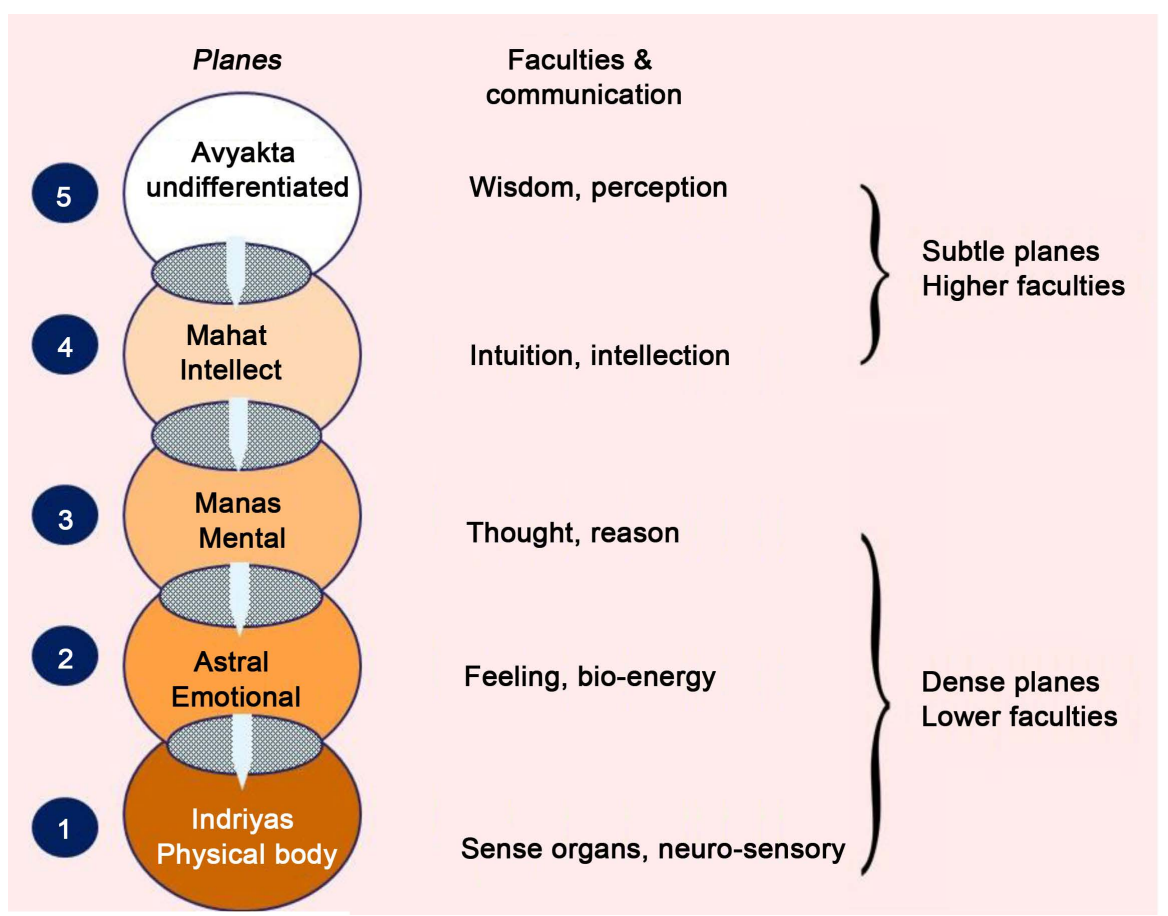

Figure 1. Planes of men (koshas), their faculties and communication system. 
of men in correlation with their faculties. These planes include physical (Indriyas), emotional (Astra), mental (Manas), intellect (Mahat) and undifferentiated (Avyakta). Most of the human beings normally exchange messages by using a communication system through lower faculties including sensory for sense organs, bio-energy for feelings and reason for thoughts. However, there are some gifted people who raise their consciousness to superior spiritual levels through intuition for immediate learning without reason and wisdom attaining direct perception of Divine Truth of akasic tables. If one person reaches these states-by the meditation technique-then he might remember and transcribe these messages in physic writing texts. In regards to Gita, while mental (probably at intellectual or buddhic level) divine dialogue was done between Krishna and Arjuna, their learnings were transcribed by Sages (like seers, gurus, swamis, pandits, etc.) to physic writing texts organized in chapters and slokas for better human being comprehension.

In the Vyasa Gita Sanskrit-English brochure from SDM by Janardana, interaction between planes and men's faculties are referred as follows: knowledge in respect of actioning should be known as having a three-fold basis viz. Manas (the faculty of Mind) that projects conceptual formations, Buddhi (the faculty of knowledge) being the determiner, and Hridaya (heart) being the seat of likes and dislikes. Sensations are subtler than senses; subtler than Sensations is manas; Buddhi is more subtle than Manas; Atman should be known as being subtler than Buddhi. Of man, his Buddhi (faculty of knowledge and discrimination) is the Atman (the Soul-principle); for Buddhi is the channel through which the Atman flows out (manifest itself). Because sense-organs have separate functionings each, Buddhi is in a continuous state of flux; ear does the function of hearing, skin does the work of touch. Looks (eyes) engender seeing, tasting is done by the pallet (tongue), by inhaling (nose) smell occurs; thus buddhi gets transformed variously. Indriya called by the name of sense-organs is the Buddhi seated in man operates mainly on a three-fold conceptual basis. Buddhi (so seated) sometimes derives pleasantness, it sorrows at other time; unsweyed by joy or sorrow, Buddhi reaches a state of yoga (synthesis) at a different time. Manas becomes and in association with sense-organs enthroned by Buddhi, functions in the field of multiplicities. Buddhi that is indivisible abides in the mind with its conceptual ideations; its outer functioning is propelled by the quality of Rajas, even the quality satwas follows similarly. The Sense-organs in association with Buddhi function for enlightening Manas or Mind; such functionings taking place with the sense-organs containing the objects as though casually, but divided willed. The Atman or the Soul-principle cannot be visioned by the sense-organs, swayed as they are by all passions, excitable (always) dreadful, untameable, and foolish. While being the witnesser of the qualitative operations, the Atman is their Director as well and when the occasion arises therefore; thus, is seen the subtle inner working of the soul and body (in union) (Janardana, 1960). 
Based on previous explanation, Sage Krishna Dwipayana Vyasa who incorporated this holy teachings of the Lord in his famous compilation Mahabharata, followed the time-honored principle the preparation of such great work generally, in framing the entire subject matter of Gita, verified by him after looking into the "akasaphalake" himself, in terms of Pranava and Gayatri, the parental basis, on which all the "Vidyas" of this land of Aryavartha have been formulated. And thus, the twenty-six chapters of Srimad Bhagavad Gita with 745 slokas got themselves fitted according to the scheme of Pranava and Gayatri (Janardana, 1952).

\section{Composition and Philosophy of Suddha Gita}

Why does Suddha Gita text contain 26 chapters? This sacred book is divided in three parts: 1) first chapter "Genesis or Gitavatara"; 2) central body called The Gayatri integrated by 24 chapters; and 3) last chapter "Brahmastuti" (Figure 2). The first (Proem \& analysis) and the last one (Epilogue \& synthesis) symbolize the Vyasthi- and Samasthi-para aspects of The Pranava. These aspects correspond to the Brahman conception of One and Many, respectively. It is so well-known that all sanskrit hymns are usually preceded and followed by the pronunciation of the Pranava. So, Gita proper is restricted to divine Gayatri of 24 chapters commencing from the $2^{\text {nd }}$ chapter "Nara-Narayanaya Dharma Gita" and ending with the $25^{\text {th }}$ chapter "Yoga Gita". These 24 chapters or adhyayas are grouped six in each, under 4 main headings viz., Gñana-, Bhakti-, Kriya- and Yoga-shatkas are known to constitute the 4 feet of the Gayatri- "Chatuspada gayatri", each of them are six-limbed representing six dharmas- "Sadangula", thus making up a total of 24 dharmas, meaning the famous 24 principles of Gayatri (Vasudeva Row, 1935) (Figure 3). Which are the symbolisms and meanings of 4 feet, 6 limbs and 24 chapters of The Gayatri? The arrangement of this text in consonance with Gayatri principle in terms of 24 or multiples of 24 is

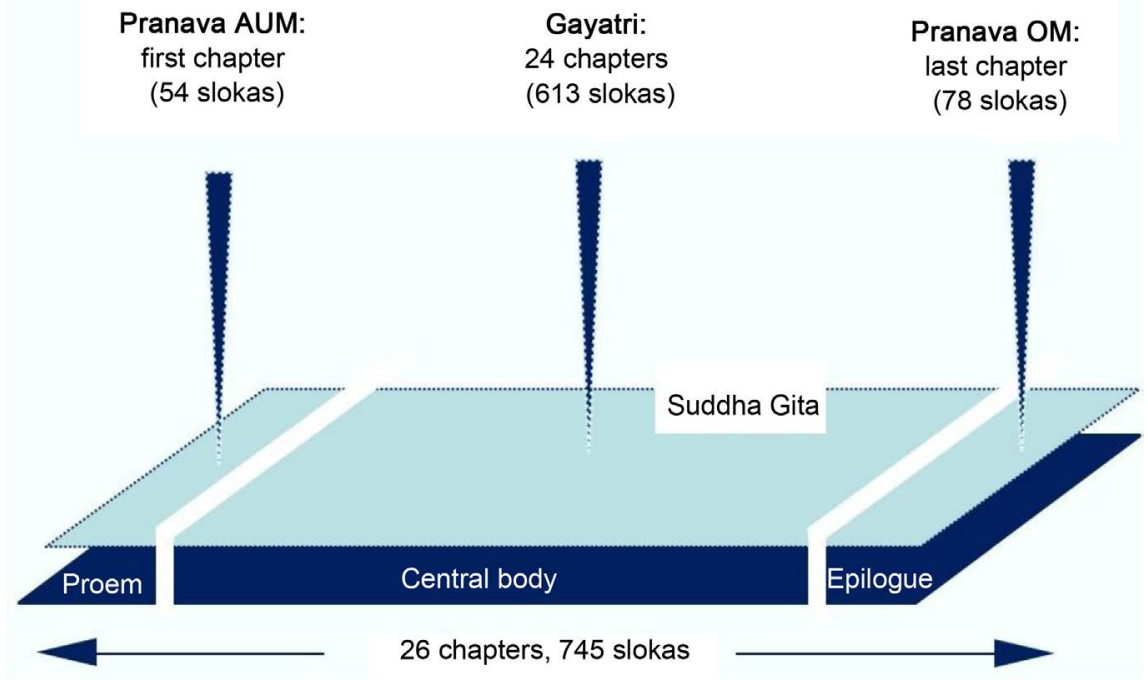

Figure 2. Composition of Suddha Gita. 


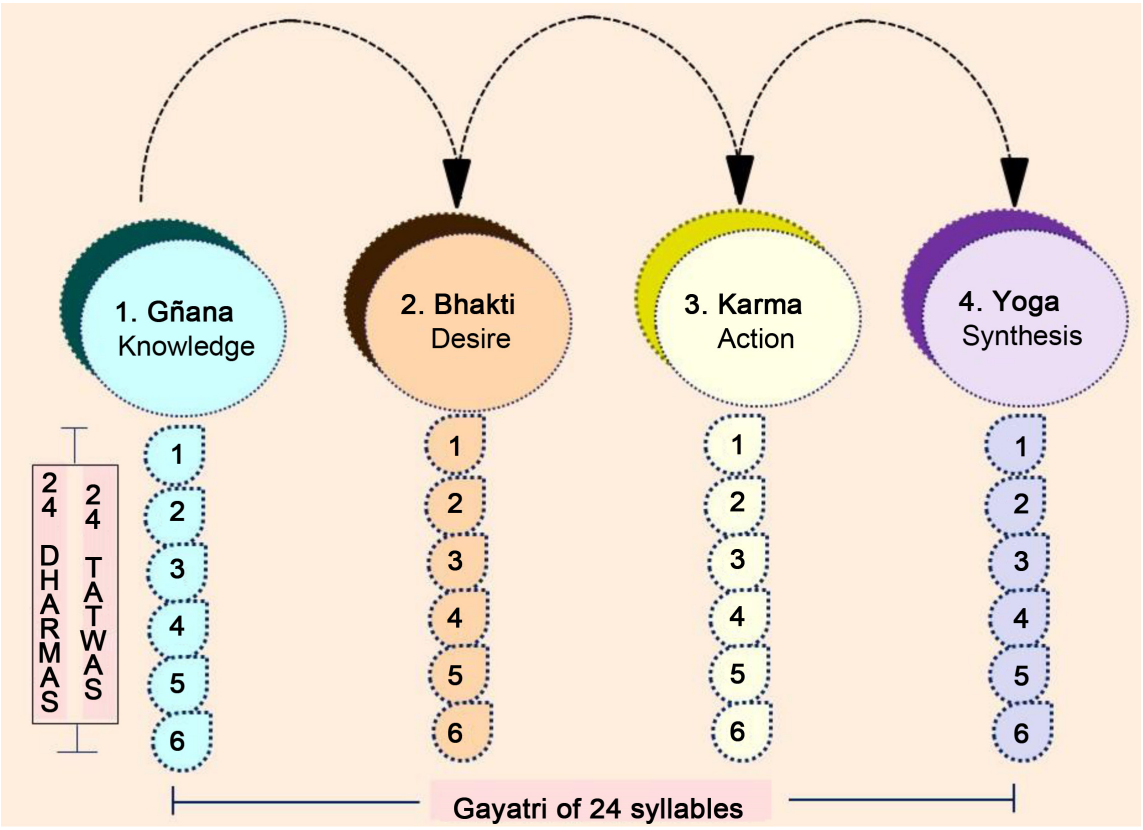

Figure 3. The Gayatri of 4 feet and 24 chapters.

not peculiar to Gita alone, besides it is instanced in the case of Ramayana with its main 6 kandas and containing exactly 24,000 slokas. Also, Bharata Samhita, source of Mahabharata contains 24,000 slokas-Caturrimsatisahasrim cakre bharatasamhitaam. This unique principle had been invariably followed in all the true ancient sacred literature. According to Hamsa Yogi-the great Sage commentator of the Suddha Gita-Srimad Bhagavad Gita is an exposition of Gayatri. In the Gita-Mahatmya of Sri Vyasnavya-Tantrsar, in the sacred names of Gita, we find that Gita is spoken as Savitri or Gayatri. Therefore, Gita is an elaborate explanation of Gayatri and its Shadhana (Nath Bose, 1952).

To a plausible question how "Gñana"-shatka could come first, the answer is, that is just in accord with the very nature of things (Figure 3). One learns or comes to know something, then he desires to have it, thereafter he endeavours for it and lastly attains it. In fact, Gñana allows the study to improve reason and intuition, Bhakti increases the will to keep the constant effort alive, Karma legitimates actions to fullfil duties and lastly Yoga synthesizes and crowns the processes allowing Divine Contact with Universal Consciousness. And as such the normal rule of life is Knowing, Desiring, Endeavouring and Attaining-Gñana, Iccha, Kriya and Yoga. Being so, nothing should be taken up for actioning without becoming previously conversant in terms of knowing and desiring, as otherwise, failure will be the result. Interestingly, there is a strong correlation between the feet of Gita (the 4 paths) and the material dense-subtle wrappers (the 4 tatwakutas) of a human being. Thus, path of Gñana-knowledge belongs to the Mahat or intellect plane, path of Bhakti-desire which correlates with Manas or mental level, path of Kriya-action that moves around Indriyas plane and the path of Yoga-synthesis acts in coordination with Avyakta or un- 
differentiated plane (Figure 4).

In other view-point of the profound connection between the Gayatri and the 4 Padas or feet, the scholar Pandit Sreenivasachariar says: "the sciences are four, the casts are four, the stages are also four in number, and the wise state that the One dharma has likewise, four Padas or feet'. The knowers of the Truth reverently accept the classification of all sciences and arts treating of dharma according to the letters in the Gayatri; that in all arts and sciences are found the teachings of the Gayatri, and that all of them have four Padas or feet. Therefore, it should be understood that the Geeta is the divine Gayatri itself and the twenty-four chapters are the twenty-four faces of the Gayatri (Sreenivasachariar, 1917). In another Suddha book called Sanatana Dharma Deepika, Vol I, Chapter first, sloka 145, establishes that: "eternal Dharma is the universally auspicious aspect of cognition, desire, action and its summation" (Yogi, 1917). In Suddha literature Hamsa Yogi was a spiritual office responsible for Suddha teachings; the philosopher Derret has speculated that the "Hamsa Yogi" was the Madras Pandit himself (Derret, 1977). Finally, the elementary criterion sense indicates that every written text in all the knowledge areas-from science to philosophy-follows the logical quadruple mentioned sequence for helping the reader to better comprehension. In conclusion Gñana, Bhakti, Karma and Yoga are the 4 feet of SDM Bhagavad Gita, the 4 pads of Gayatri, the 4 aspects of eternal Dharma and the 4 keys for life learning. All these aspects might be summarized as the quadruple life-path.

The greatest symbols known to civilized man are The Pranava or the syllable Om and The Gayatri consisting of 24 syllables. Pranava contains 2 expressions: 1) the analytical three-letters AUM which normally appear at the beginning of important mantras, where the first letter represents Atma or the Self-aspect of Brahman; U the Prakriti or the Not-self aspect; M the Shakti or the Force-aspect; 2) the synthetical two-letters OM which normally appear at the end of important mantras, where $\mathrm{O}$ (pronounced at center of the palate) integrates the 2 extreme vowels and M similar like before. The AUM at the beginning signifies that

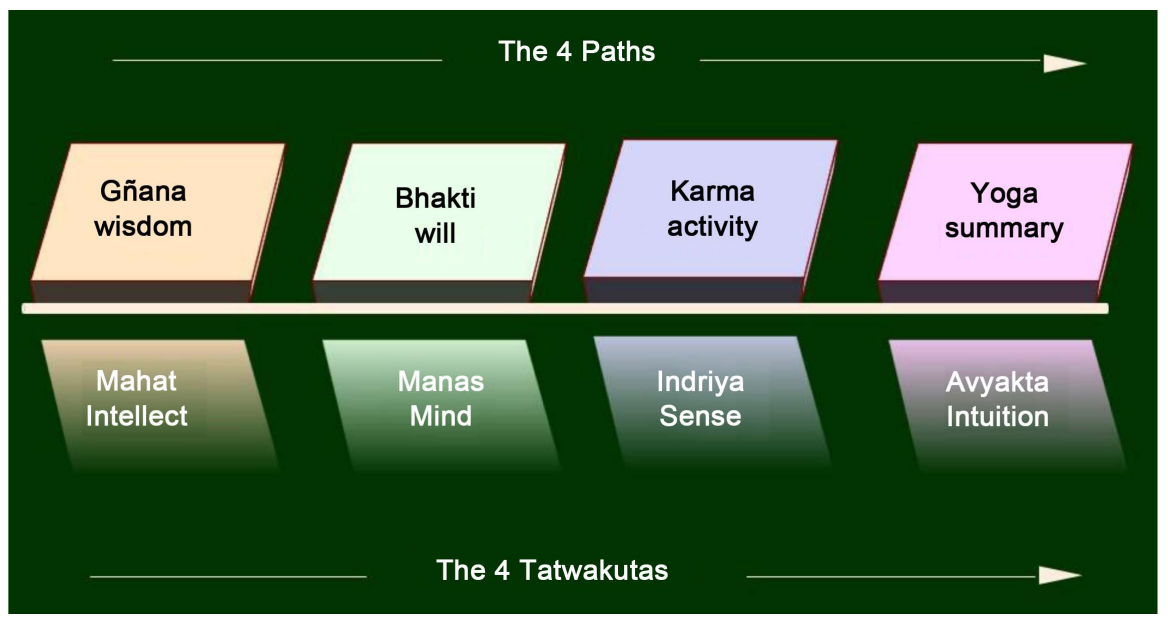

Figure 4. Correlation between paths and material planes (tatwakutas). 
Brahman is the source from which the factors manifest themselves, and Om at the end signifies that these factors merge and become synthesized in that very Brahman. By the other hand, the 24 syllables of Gayatri including: tat-sa-vi-tur-va-rè-ni-yam-bhar-go-de-va-sya-dhee-ma-hi-dhi-yo-yo-nah-pra-c ho-da-yat. Of this symbol, the former was, if one may say so, of primeval origin. At all events, it was pre-Aryan as is evident from the mantra "Om mani padmè hum", still in use in those countries where the blood in the bulk of population is Atlantean. The author of Suddha Gita also points out that 24 great factors enter into the constitution of manifested cosmos, including, of course, the evolution of our own humanity. Those factors, in the technical language of the books, are the twenty-four tatwas (Figure 3) evolved out of the Matter-aspect of Brahman called moola-tatwa in the Yoga-deepika, by the Force-aspect of Brahman called babu-bhavana-maha-sakti according to the ideation of Brahman's Self-aspect, the Paramatma. The tatwas, in question, consist, as it is well-known, of the five mahabootas or the elementary substances which are the prototypes of what, in our own physical plane, are called earth, water, fire, air, and ether; the five tanmatras or the vibratory rates which regulate and govern the guna or quality peculiar to each of the mentioned five elements; the five karmendriyas or motor-organs; manas, the organ of ratiocination and intellect; buddhi, the organ of intuition; ahamkara, the organ of egoism or the "I"; and the avyakta, the subtlest undifferentiated organ of Atma or the Monad (Sreenivasachariar, 1917). While Gayatri is the 24 mentioned material-tatwas, Pranava is the twenty-fifth tatwa known as the Purusha, immortal the all-formed and nearest in the hearts of the wise.

The last feature of the arrangement which requires notice is, that each of the four groups (foot) of Gayatri consists of six chapters (fingers). The reason is that this number has also been used as a technical sign related to the duties incumbent upon a member of Aryan society according to the sacred Books. These duties, in relation to a person who is an aspirant for liberation, to be as follows: 1) Adhyayana or study of Brahman in the light of symbol Pranava; 2) Adhyapana or teaching that we are all equals; 3) Yajana-attitude which enables the aspirant to stand with his own Higher Self as well as the Supreme Self; 4) Yajana-sacrifice for others is the seeing of himself everywhere; 5) Dana or surrender of the Self to Brahman through meditation on the Absolute (suddha-yoga); and 6) Pratigraha or preserving of the body for the purpose of observing Dharma.

No reference has been made to the reason for the introduction by the author of the first and the twenty-sixth chapters and his linking them with the body of the twenty-four chapters compacted together under the four groups. The obvious explanation is that the Gayatri can never stand by itself but only in relation to the Pranava which is its one basis and support. In actual practice too, the Vedic mantra of the twenty-four syllables is uttered with an Om at the beginning, that is, before the syllable tat, and another at the end, that is, after the syllable yat. The two Oms represent Brahman, the substratum of the twenty-four primary factors to which the twenty-four chapters correspond. The primordial 
sound $\mathrm{OM}$ emerges from the depths of transcendence giving rise to the Life Processes and the multiplicity of forms, whose expressions are called Gayatri. Therefore, The Gayatri is the expression of sound as omnipresent and omniscient knowledge, where the One and the Multiple are established. The principle of Pranava $O M$ expressed as multiple shapes mystic syllables constitutes the wisdom of life. These syllables have been built by wise teachers, who by their degree of development have accessed to the planes of sound (ether or Akasha). The sacred monumental text of Pranava OM from the Order of SDM contains complete information about the mysteries of the sound OM (Sreenivasachariar, 1915).

The Supreme Brahm as One and Many is also correlated with "Bhavana", a Sanskrit expression reflecting the Unity in the Diversity where we are embodied spirits. The Sage Hamsa Yogi explains that Bhavana constitutes the first of three components of Suddha Discipline of Raja Yoga, which is settled as follows: "Unity exists in the entire creation comprising devas, men and animals and all those envisaging animate life, the capacities and powers inherent in them, the various locations or worlds and the several laws by which they are governed; all are born of the very nature of Supreme Brahm in their very being, should be retained in memory" (by Dasas or disciples of SDM) with a pure undistracted mind (Janardanam, 1946).

Figure 5 summarizes the philosophical essence of Suddha Gita which it begins with "The Pranava syllable AUM", it continues with "The Gayatri vedic mantra 24 syllables", and it ends with "The Pranava syllable OM". Thus, Suddha Gita text is an integration of PRANAVA (Universal Sound) and GAYATRI (Universal mantra).

\section{Followers and Detractors of Suddha Gita}

SDM Gita edition 1917 had been followed and approved by more than thirty

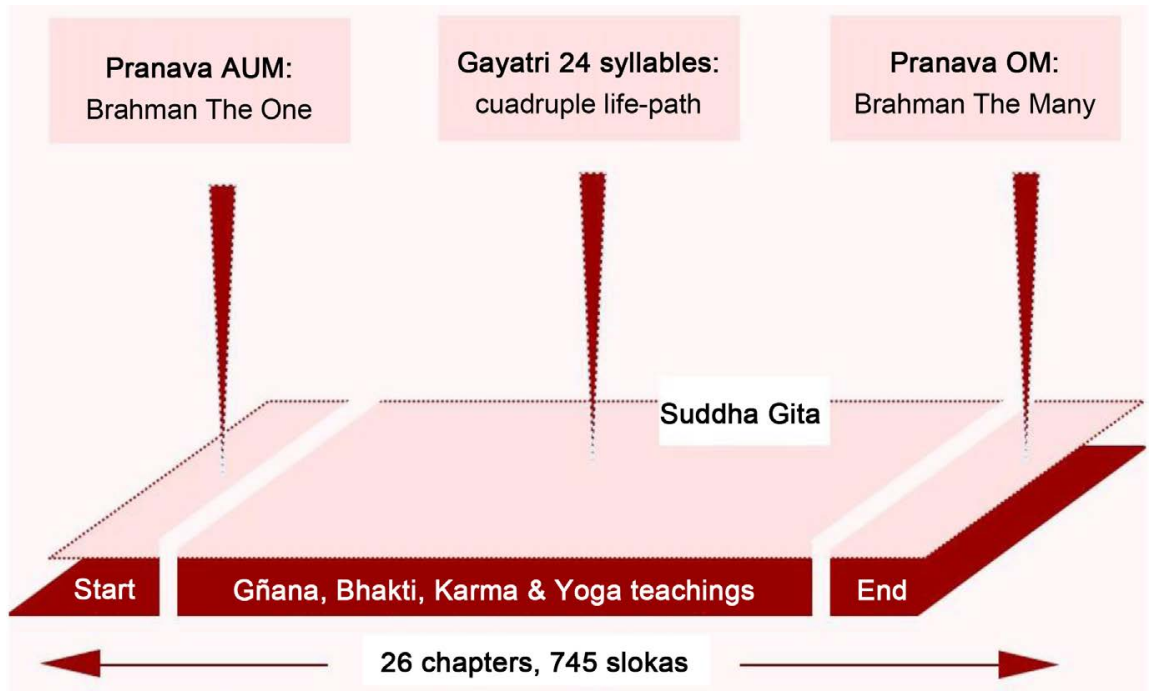

Figure 5. Philosophy of Suddha Gita: Pranava + Gayatri. 
Acharyas like Gobhila, Narada, Kumara, Hamsayogi, Tamkacharya, Samkara Bhagavan Maharisi, Bodhayana, Angirasa, Kasyapa, Yagnavalkya, Kanva, and others. However, detractors are expected (Bhattacharya, 2013; Vedavyas, 1990; Schrader, 1938); for instance in 1938 the German Professor Otto Schradermade severe criticism to Suddha Gita including: the artificial text composition because it contains 26 adhyayas and not 18 chapters, the total 745 slokas text resulting from addition or omission compared to the current recension of 700 slokas, and the lack of sense of propriety and historical sense (Schrader, 1938). Curiously, at the beginning this philosopher had accepted the Gita edited by SDM with pleasure, but his position changed 20 years later focusing the attention on "text writing syntax" to explain disagreements and convince others. More recently, Adluri and co-worker (Bagchee \& Adluri, 2016) in his review article also support the traditional Gita of 18 chapters and in relation to SDM Gita said: "Suddha Gita is not read today".

\section{Discussion}

Ancient recensions. it is quite obvious that the epic theme of the Gita is a report made by Samjaya to the blind King Dritharastra by narrating the holy dialogue between the Lord and Arjuna, at the commencement of the contention. As mention before this dialogue was incorporated by Sage Krishna Dwipayana Vyasa in the Mahabharata, and the division into chapters and verses had the sanction of "Pranava-sastra" which the Sage followed in his great compilation. This information was furnished in the article "The Genesis of the Mahabharata" by Sri R. Vasudeva Row, which appeared in "The Suddha Dharma”, Madras, March 1935 issue (Vasudeva Row, 1935). He has also given out therein a table regarding the names of Parvas and Suparvas with the distribution of slokas. So that, distribution was not arbitrarily made, but it did follow a well-ordered scheme.

The profound theme of Gita was studied in various recensions prior to the days of Shankara in the different schools of thought prevalent then. For instance, School of Bhargava Bharata studied Gita with 6 chapters and 144 slokas. Sootra Bharata School, with 4 chapters and 96 slokas. Vasta Tatwagnanas, with 3 chapters and 72 slokas. Pranaoaria Vignnanis 4 chapters and 96 slokas. Samasti Prananvnthapara School with 1 chapter and 8 slokas. And it is in Mahabharata of Krishna Dwipayana Vyasa, that Gita is 26 chapters and 745 slokas. Although all these schools had different orders of chapters and verses, expatiated, only on the one central theme of Gita which is Yoga Brahma Vidya and the number 24-the sloka measures for each chapter adopted by all these schools-is to constantly keep, the 24 tatwas of Gayatri, the basis for all knowledge formation, "tatwa vidya is gayatri, in addition to its being mantratmika also to be toned as japa".

Current recensions: the current text of Gita has given room to ideological differences and controversies by various schools, each trying to decry the others and maintain its own view-point, whereas the Suddha text though read in different textual versions by various schools, there had been no ideological differ- 
ences at all and each school supplemented the thought of the other in regard to the one great ideology thereon. Similarly, the moderns need not to confine their differences to the commentaries only, since they can have their own texts of Gita, if they want, because there is no sacredness regarding the form of a text. Sacredness and purity belong to ideological concepts-bhava samsuddhi. The whole of current recension is divided into 18 chapters and empirically divided into three shatkas-Kriya, Bhakti and Gñana shatkas, which are based on "tripada gayatr", although Gayatri to be complete has to be "chatuspada-shadangula" representing the well-known 24 principles, six in each pada. The absence, thus, of a fourth pada as such, which is Yoga-pada synthesizing Gnana, Iccha and Kriya, is an omission of the first-class magnitude detracting the worth of the current recession as a competent compilation. This omission cannot be got by stating that the word "yoga" is attributed to each chapter, since no sanskrit work-ancient or modern-sanctions the naming of chapters as "Yoga". Also, the term "gitasu" at the end of each chapter proves beyond any shadow of doubt that the Bhagavad Gita is a collection of various chapters called "gitas" by themselves, and not "Yogas". I must remember that each chapter of the Suddha text is named a Gita.

By itself, the examination of a classical text in regard to its form alone to determine its age is a nonsense parameter to hold a sacrosanct text. Generally, according to ancient usage, sloka-texts were divided into chapters and verses from the adhyayana and adhyyapana point of view, that is to say, to facilitate the study and learning as well as the imparting of the theme of knowledge. As there is no question on how a text has to be for the knowledge, the basis and the theme set forth are more important and the text can be shaped and formed in any way with variant sloka-readings also to suit the need, provided that, the central theme is correctly understood and conveyed in the texts. In this connection Hamsa Yogi says- "thus is seen the order of the number of Gita slokas in the previous Dharsanas: whereas, Krishna Dwipayana Vyasa, knowing that the Yogi Samjaya, who had his own Yogic strength, having realized the substance of the oral teaching of Bhagavad Gita by Narayana to Partha and recorded in the Akasic (ether) tablets explained it to the King Dhritarashtra in 576 slokas divided under 24 headings", incorporated them (in his Mahabharata) in 26 chapters of 745 slokas.

For centuries, the Geeta has been known to consist of only eighteen chapters; as such indeed did the great men of yore who interpreted the Geeta, Sankara (8th century Indian philosopher who consolidated the doctrine Vedanta) and others, together with their followers, accept it. Had they been aware of this other Geeta prized by the Suddhas, wouldn't they have made at least a single reference to it in their works, was it only to disagree with its drift and teachings, refute and condemn it, and thus strengthen the cause of their own doctrines they expounded?. It must now be abundantly clear that it is against all argument to say that the Geeta of the Suddhas cannot be authentic simply because great men of the past have not referred to it, in works mainly controversial, where they sought 
to confound their opponents by loudly setting forth their own doctrines. In Sankara's own work, in the foreword which he has prefixed to his commentary of the Geeta, it can be proved conclusively that portion of the text from "Narayana is higher than Mulaprakriti" to "To explain which I shall now attempt" coincides with Suddha text that begins with Narayanaya-Dharma Geeta and ends with Yoga-Geeta. Thus, suffice it to say that Suddha Geeta can no longer be rejected or disapproved (Sreenivasachariar, 1917).

Contemporary recensions: in 1947 the Hindu Philosopher S. K. Belvarkar rejected Schrader's claims regarding the authenticity and priority of Kashmir recessions (Belvarkar, 1947). Later on, the year 2007, the American Theosophist David Reigle from the Eastern Tradition Research Institute points out that SDM Gita in content does not vary substantially from the standard or "normative" version, and it is more a matter of the book's arrangement; the Suddha version has 745 verses in 26 chapters, compared to 700 verses in 18 chapters in the standard version (Reigle, 2007); for this author, to argue that additions or omissions to accommodate the number of verses is an absurd and inappropriate criticism. It is more relevant to pay attention to the integrator common aspects than fixing attention to segregator textual forms. Finally, the recent comments from Bagchee \& Adluri are wrong and disrespectful, since today Suddha Gita text is totally valid and read by a lot of people around the world. Actually, the Order of SDM as philosophy and outer organization has many schools distributed in different American and European countries including Argentina, Brazil, Canada, Chile, Spain and France.

\section{Conclusion}

In the Universe the Bhagavad Gita-the Yogic art of Brahman-occupies the most exalted position. As expected, different commentators differently commented upon the mystic meaning. Gita with its rich and many-sided expression of thoughts, its synthetical grasp of Karma, Bhakti and Gñanam is unique in the world.

While mental divine dialogue was done between Krishna and Arjuna, their learnings were transcribed by Sages to physic writing text organized in chapters for human comprehension. Suddha Gita contains 745 verses in 26 chapters conformed by dual extreme "The Pranava" (first \& last chapters) and central body "The Gayatri" of 24 chapters (4 feets). The first (Proem) and last one (Epilogue) represent Vyasthi- and Samasthi-para aspects of The Pranava; these aspects correspond to the Brahman conception of One and Many. While the 4 feet (Gñana-knowledge, Bhakti-desire, Karma-action and Yoga-synthesis) correspond to 4 aspects of eternal Dharma and the 4 keys for life learning, the 24 chapters represent the 24 material tatwas.

Today Suddha Gita is valid and it is being read by many people around world, since SDM Order as an outer organization has several schools distributed in American and European countries. 


\section{Conflicts of Interest}

The authors declare no conflicts of interest regarding the publication of this paper.

\section{References}

Bagchee, J., \& Adluri, V. (2016). Who's Zoomin' Who? Bhagavadgita Recensions in India and Germany. International Journal of Dharma Studies, 4, 1-41. https://doi.org/10.1186/s40613-016-0026-8

Belvarkar, S. K. (1947). The Bhismaparvan for the First Time Critically Edited. Pune: Bhandarkar Oriental Research Institute.

Bhattacharya, S. (2013). The Original Bhagavad Gita. Complete with 745 Verses. Delhi: Parimal Publishers.

Derret, J. (1977). Essays in Classical and Modern Hindu Law (Vol. 2) Consequences of the Intellectual Exchange with the Foreign Power. Leiden: Brill.

Janardana, T. M. (1951a). Suddha Dharma Mandalam, the Divine Hierarchy, Its Scope and Purpose. Mylapore: The Suddha Dharma Office.

Janardana, T. M. (1951b). SDM Gita Texts Divine Source. Suddha Dharma, 7, 1-14.

Janardana, T. M. (1952). Epitome of the 26 Chapters of Sri Bhagavad Gita as Given by Sri Hamsa Yogi. The Suddha Dharma, 8, 25-30.

Janardana, T. M. (1960). Vyasa Gita, Transliteration and Translation. Mylapore: The Suddha Dharma Centre.

Janardanam, T. M. (1946). Suddha Raja Yoga of Sri Hamsa Yogi (Text with English Translation). Mylapore: The Suddha Dharma Office.

Nath Bose, J. (1952). The Original Gita. The Suddha Dharma, 8, 20-23.

Reigle, D. (2007). Publications of the Suddha Dharma Mandala (pp. 1-17). Cotopaxi, CO: Eastern Tradition Research Institute.

Schrader, F. O. (1938). An Implication of the Bhagavadgita Riddle. New Indian Antiquary, 1, 62-68.

Sreenivasachariar, K. T. (1915). The Pranava-Vada of Maharshi Gargyayana and Pranava Vadartha Deepika, of Swami Yogananda (Vol. I). Mount Road: Modern Printings Works.

Sreenivasachariar, K. T. (1917). Bhagavad-Geeta and the Geetartha-Sangraha of Maharshi Gobhila. Suddha Dharma Mandalam Series No. 3. Madras.

Subramania Iyer, S. (1915). An Esoteric Organization in India. The Theosophist, 36, 407-411, 499-517, 614-626. https://doi.org/10.1246/nikkashi1880.36.407

Vasudeva Row, R. (1935). Srimad Bhagavat Gita. The Genesis of the Gita. The Suddha Dharma, 2, 220-222.

Vasudeva Row, R. (1938). The Heart-Doctrine of Sri Bhagavad Gita \& Its Message (In Terms of Adhividya). Mylapore: The Suddha Dharma Office.

Vedavyas, E. (1990). Ancient Bhagavad Gita: Original Text of 745 Verses, with Critical Introduction. Hyderabad: United Social Cultural and Educational Foundation of India.

Yogi, H. (1917). Sanatana Dharma Deepika, or Anushthana Chandrika (Vol. I). Madras: Modern Printing Works. 